\title{
HVAD RELIGION ER, FORTALLER HISTORIEN OS
}

\section{Om forholdet mellem historievidenskab og religionsvidenskab}

\section{Af Kurt Rudolph}

Titlen på mit foredrag ${ }^{1}$ er en omskrevet sætning af Wilhelm Dilthey, der i et udkast, kaldet »Drøm«, til en tale på sin 70 års fødselsdag i 1903 har udtalt: Was der Mensch sei, sagt ihm nur seine Geschichte. ${ }^{2}$ Bagved ligger Diltheys historiske erkendelse af menneskets endelighed og betingethed af fortiden, som man ikke kan kaste fra sig som en frakke. »Vort livs melodi er betinget«, fortsætter han,

af fortidens ledsagende stemmer. Mennesket kan kun befri sig fra øjeblikkets pine og fra enhver glædes flygtighed ved at give sig hen til de store objektive magter, som historien har frembragt. ${ }^{3}$

Sandsynligvis er denne bekendelse typisk for slutningen af det 19. århundrede, historievidenskabens og filologiens store århundrede. Den viser os konsekvenserne af den historiske bevidsthed, som opdyrkedes så enormt, ja egentlig grundlagdes netop i dette århundrede. Dens relativerende konsekvenser har Dilthey et andet sted beskrevet således: »Den historiske relativismes kniv, der på en måde har skåret al metafysik og religion i stykker, må også føre til helbredelsen $\kappa^{4}$ Diltheys mislykkede fors $\emptyset \mathrm{g}$ på at tilvejebringe denne helbredelse med en livsfilosofisk medicin kan ikke forfølges videre her, hvor vi skal se på religionens - tillad mig anvendelsen af ental - rolle som en af disse »store objektive magter «. Og her gælder det om at huske på, at ingen ringere end Schleiermacher - som Dilthey jo beskæftigede sig med gennem hele livet nærede den opfattelse, at »historien altid er religiøs, og at religionen ifølge sin natur må være historisk «. ${ }^{5}$ Historie som religion, religion som historie - begge dele hører til den moderne teologis og den religionsfilosofiske historiebetragtnings credo, som hos Tillich kulminerer i den dialektiske opfattelse, at det ubetingede (dvs. religionen eller Gud) er 


\section{Hvad religion er, fortæller historien os}

kulturens grundlag (og at kulturen omvendt er en betingelse for, at religionen kan manifestere sig). For så vidt er sætningen »Hvad religion er, fortæller historien os«, helt igennem træffende.

Der er ingen som helst tvivl om, at beskæftigelsen med religion eller religiøse fænomener $\mathrm{i}$ fortid og nutid ikke kan ignorere den historiske dimension. Religion - jeg tillader mig fortsat at bruge ordet i ental - er i alle samfund og alle kulturer en traditionel "magt«, man ikke kan se bort fra. Den historiske side af religionen er således i alle tilfælde en legitim indgang til dette "fænomen«. Problemet melder sig så, hvis man vil betragte denne tilgang som den eneste gyldige. I religionens selvforståelse betragtes den historiske dimension - for så vidt som den overhovedet tematiseres - som blot en "ydre « side af religionen, mens "religion« eller »tro« går på noget »indre«, indbefattet et overmenneskeligt eller endda overjordisk aspekt. Dette er det religiøse og teologiske standpunkt, for hvilket historien primært er en »inkarnation « af en evig sandhed: den synlige, håndgribelige side af en evig væren, som kun er tilgængelig for den troende.

Min foredragstitel rejser altså samtidig det fundamentale, til stadighed omdiskuterede problem om den rette tilgang til religion: Hvis den religiøse betragtning hos »insideren« er den eneste rigtige, så er den anden, den hos »outsideren«, kun en »ydre«, en »overfladebetragtende«. Dette gamle stridsspørgsmål, som vi dog ikke vil beskæftige os videre med, har forståeligt nok præget religionsvidenskabens forhold til teologien og til den religiøse selvforståelse indtil den dag i dag. En løsning er kun mulig, hvis man gør sig de involverede parters forskellige betragtningsmåder helt klart. Troens standpunkt er et andet end videnskabens, men de to standpunkter kan - og gør det ofte - falde sammen, når en »insider « midlertidigt bliver »outsider «, således som tilfældet er for flertallet af religionshistorikere og historiske teologer. Så skærer cirklerne hinanden, og der opstår en dobbelt refleksion, ja en art dialektisk formidling af tro og viden. Det uigenkaldeligt nye ved vor situation er imidlertid den erfaring, som Dilthey og mange andre moderne historikere har gjort, af den relativerende tænkning, som »outsider«-positionen skaber, og som ikke kan undgå at påvirke »insider-rollen«. Omvendt har den religiøse, kulturbestemte betragtning dog også indflydelse på den 


\section{Kurt Rudolph}

videnskabelige, noget der ofte glemmes - om end man i den seneste tid i stadig højere grad har set en kritisk refleksion i forhold til vor eurocentriske, antikt-kristelige betragtningsmåde, herunder også selve vort religionsbegreb. ${ }^{6}$

Religionsvidenskaben har haft denne dobbeltstilling siden sin start, den er en del af dens historie. Den dikotomi mellem faktaerkendelse og norm- eller værdierkendelse, som vi kender inden for alle kulturvidenskaberne, har i religionsvidenskaben et særligt præg, fordi videnskabens genstand gør krav på at have en grænseoverskridende tendens - noget der først og fremmest ses $\mathrm{i}$ de store religioners traditioner (kristendommen, islam, buddhismen osv.). Den religionshistoriske betragtningsmåde blotlægger mangfoldigheden i religionernes verden og spolerer det uniforme syn i enhver fænomenologisk eller filosofisk »væensbetragtning «。 En historisk fremtrædelsesforms »væsen « (essentia) er for os i dag ikke længere noget, der kun kan begribes intuitivt, men ligger $\mathrm{i}$ fænomenets historie, i dets strukturer og symbolsystemer, som er tilgængelige med de forskellige videnskabelige metoder. Derfor er talen om religion i ental efter en nutidig forståelse også en relikt fra en forgangen periode i religionsvidenskabens historie, der i sin spørgen efter religionens oprindelse - i øvrigt et for det 19. århundrede meget karakteristisk forehavende var præget af en sådan forgæves eftersøgning af fænomenets væen. »Religioner« eller - for blot en enkelt gang at opgive det belastede, latinsk-kristelige begreb - sagforhold eller kendsgerninger i kultur, samfund og overlevering er, hvad religionsvidenskaben har som sit objekt, eller i det mindste gør krav på at have.

Når jeg har sagt, at hvad religion er, det fortæller historien os, så skal det derfor tages cum grano salis. Det skal forstås på den måde, at de religiøse forholds historiske dimension ikke kun ubestrideligt har udgjort en side af menneskelig tænken og handlen lige indtil vor egen tid og p\& denne måde viser os sin mere eller mindre ubrudte magt, men at den netop ved at være snævert kædet sammen med de pågældende religioners historie og kultur viser mere om deres såkaldte »væsen« end det så ofte påkaldte »hemmelighedsfulde« (læs »mystiske«) eller »esoteriske«, som kun er tilgængeligt for åndsbeslægtede eller intuitivt-religiøst begavede (som Rudolf Otto og hans adepter). 


\section{Hvad religion er, fortaller historien os}

Dermed har jeg allerede berørt tematikken i det forhold mellem religionsvidenskab og historievidenskab, som nu skal beskæftige os. Jeg vil gøre det $i$ tre afsnit:

- et kort første afsnit om religionsvidenskaben som historisk-filologisk disciplin,

- et andet afsnit om de vigtigste nye sider af historievidenskaben og deres ændringer,

- et tredje afsnit med nogle konsekvenser heraf for den nutidige religionsvidenskab.

\section{I}

På basis af de udredninger, jeg har givet $\mathrm{i}$ det foranstående og i mine hidtidige arbejder, er det bekendt, at jeg betragter religionsvidenskabens filologiske og historiske tradition som et umisteligt grundlag for faget. ${ }^{7}$ For mange forskere inden for den moderne religionsvidenskab, der jo i det engelsk-amerikanske sprogområde har mange navne (Religious Studies, History of Religions, Studies in Religion), er dette formodentlig ikke altid forståeligt, og det kan opfattes som gammelt arvegods fra det 19. århundrede. Jeg vil derfor godt endnu engang kort angive, hvad det er det kommer an på for mig med denne understregning:

1. Det, som vi internationalt har vænnet os til at kalde "religion«, er en integreret del af kultur, historie og samfund, som vi hyppigt kun på en temmelig kunstig måde kan rekonstruere som et særligt felt, eftersom det i praksis ikke forefindes og artikuleres som en uafhængig sektor. En fagdisciplin, der vil beskæftige sig med dette objekt - enten som sådan eller i dets forskellige aspekter -, må derfor nødvendigvis først og fremmest være historisk anlagt. Derved kan f.eks. den for religionsvidenskaben så vigtige etnografi ligeledes forstås som en i det væsentlige historisk disciplin, der som alle andre discipliner af denne art dog samtidig indeholder andre betragtningsmåder (antropologiske, sociologiske, økonomiske osv.).

2. For historiske samfund, som besidder en skriftkultur, er det i første række skriftlige »kilder « af forskellig art, der foreligger, og derfor er kilderne for den pågældende religions vedkommende også kun tilgængelige ved hjælp af filologiske midler (at der bag begrebet »kilde« 


\section{Kurt Rudolph}

ligger et typisk synspunkt fra det 19 . århundrede, må vi her lade hvile). ${ }^{8}$ Derfor har det filologiske arbejde helt tilbage fra den moderne religionsvidenskabs grundlæggelse stået i forgrunden. Den »filologiske erkendelse (P. Szondi) $^{9}$ er en væentlig side også af religionsvidenskaben, eftersom sprog og litteratur ofte vil være en af religionens vigtigste manifestationer (her skal kun erindres om de hellige skrifter og den litteratur, der slutter sig dertil) og derfor vil være selve adgangsvejen til en religions eller et religiøst sagforholds historie.

3. Begrebet »filologi« undergik allerede i det 19. århundrede en betydelig ændring, og det netop inden for den klassiske filologi. August Boeckh og derefter især Ulrich von Wilamowitz-Moellendorff brød med det traditionelle begreb om filologi som en ren beskæftigelse med sprog, tekstkritik og grammatik og indsatte i stedet beskæftigelsen med hele den antikke, dvs. græsk-romerske, kultur. Filologiens genstand blev for dem det græsk-romerske liv i kultur og historie; filologien blev derfor til en historisk disciplin, til Altertumswissenschaft i den nutidige betydning. ${ }^{10}$ Ingen ringere end Theodor Mommsen havde allerede før Wilamowitz taget dette skridt. Det er derfor tydeligt, hvad der skjuler sig bag det noget belastede begreb filologi, når filologen og religionshistorikeren Albrecht Dieterich i 1904 på den 2. religionshistorikerkongres i Basel udtalte, at »filologi, forstået som den videnskabelige udforskning af et folks kultur i dens helhed«, hørte til religionsvidenskabens grundlag. ${ }^{11}$ De orientalske og moderne »filologier«, der opstod i tilknytning til og med den »klassiske« filologi som forbillede, optog netop dette program $^{12}$ og har derfor også sat et stærkt præg på religionsvidenskaben. Talen om »filologisk-historisk « er derfor en slags pleonasme, der udtrykker, at der i grunden hverken gives filologi uden historie eller historie uden filologi; begge er kulturvidenskaber, der har stor betydning for religionsvidenskaben og garanterer den et fast fundament.

4. Om det lige fremhævede fundament drejer det sig også, når religionsvidenskaben vil løsgøre sig fra den gamle afhængighed af metafysik henholdsvis filosofi og teologi i snævrere betydning, hvad den jo i vid udstrækning allerede har gjort (selv i Tyskland). Den filologisk-historiske metode har bidraget væsentligt hertil ved at placere mange religionsvidenskabelige teorier på fødderne i stedet for på hovedet. Jeg erindrer 


\section{Hvad religion er, fortaller historien os}

om, at det var den såkaldte »religionshistoriske skole « inden for den protestantisk-liberale teologi i Tyskland, der begyndte med at underkaste den tidlige kristendom den samme betragtningsmåde, som religioner uden for Europa allerede var blevet betragtet med. ${ }^{13}$ At skrive urkristendommens religionshistorie vil ifølge William Wrede sige,

at skrive således, som man ellers skriver et kapitel af den almindelige religionshistorie... Man kan sige, at den religionshistoriske behandling her ikke betyder andet end en realhistorisk. ${ }^{14}$

Med rette kan Dilthey på lignende måde kort og godt erklære: „Den religionshistoriske metode er blot anvendelsen af den almindelige historiske metode på dette særlige objekt «. ${ }^{15}$ Konsekvenserne af denne anvendelse er vi umiddelbart fortrolige med den dag i dag, hvor den dokumenterer virkningen af en filologisk-historisk metode på vor egen religi$\emptyset$ se tradition. Når teologien i dag lever i et spændingsfelt mellem de historiske discipliners relativerende arbejde og dogmatikken og etikkkens normative arbejde, så er det en konsekvens af den religionshistoriske betragtning, der indebærer en ideologi- og normkritisk tendens, som vi skal komme tilbage til.

5. Sluttelig skal det tilføjes, at den filologisk-historiske metode ikke gør krav på at være den eneste anvendelige, men tværtimod er klar over, at den kun er én af de metoder og heuristikker, der er nødvendige for religionsvidenskaben. Det gælder naturligvis i dag i endnu højere grad end tidligere. Også under ændrede betingelser må den filologisk-historiske metode imidlertid insistere på kravet om at yde et grundlæggende arbejde, der er bestemmende for selve religionsvidenskabens karakter. Som vi straks skal vise, hører sociologiske, økonomiske, sociometriske, geografiske og andre undersøgelser nu mere end tidligere med til de historievidenskabelige arbejdsmåder. De hører altså med til historikerens værktøj, som også religionshistorikerne, hvis de ikke allerede gør det, må betjene sig af. 
II

At ville give et overblik over historievidenskabens forandring i den nyeste tid grænser til formastelighed. For det første er jeg ikke såkaldt "profanhistoriker«, for det andet er min synsvinkel naturligvis begrænset, både regionalt og generelt. Når jeg alligevel taler derom, bliver det i det væsentlige ud fra tyske forhold. Jeg vover trods alt at gøre mine bemærkninger, idet jeg i næsten 15 år har repræsenteret mit fag, religionshistorien, $\mathrm{i}$ en afdeling for historie, om end under specielle omstændigheder og ikke til religionsvidenskabens absolutte fordel. ${ }^{16} \mathrm{Jeg}$ er derigennem blevet konfronteret med historiske problemstillinger i stærkere grad, end det ellers er tilfældet ved religionsvidenskabens placering i det akademiske rum. I grunden er en indplacering af religionsvidenskaben eller religionshistorien i det historiske fagområde slet ikke så dårlig: Den frembyder en ganske anden horisont, end når religionsvidenskaben eller religionshistorien har hjemme inden for f.eks. teologien.

For den, der bare i et vist omfang har fulgt den historievidenskabelige diskussion i de sidste 20 år, tegner der sig en enorm forandring i to henseender: for det første historieskrivningens brede åbning over for sociologien og samfundsvidenskaberne, for det andet indsigten i teoriernes nødvendighed ved udøvelsen af det historiske håndværk. Begge dele hænger efter min mening umiddelbart sammen, da de sociologiske problemstillingers indtog $\mathrm{i}$ historievidenskaben nødvendigvis måtte føre til en opgivelse af den næsten klassiske teorifjendtlighed i denne disciplin, eftersom sociologien netop er en meget teoriåben disciplin. Hvad historievidenskabens åbning over for sociologien angår, så udgør den i dag i vid udstrækning ikke længere noget problem. Både i Frankrig og i USA er fænomenet meget ældre end i Tyskland. I Tyskland gjaldt indtil efter 2. Verdenskrig historismen som $\gg$ de dannedes sidste religion $\ll{ }^{17}$ En koncentration om ideerne, de store individer, staternes udenrigspolitik, »forståelsen« som det primære kendetegn ved historievidenskabeligt arbejde - det var de herskende temaer. Afvisningen af sociologien eller samfundsvidenskaben havde en længere historie, som jeg ikke skal tage op her (jeg skal blot minde om striden omkring Leipzighistorikeren Karl Lamprecht) $;{ }^{18}$ den har rødder $\mathrm{i}$ en afstandtagen fra marxistiske ideer og i en mangel på teoretisk refleksion over sammenhængen mellem økono- 


\section{Hvad religion er, fortaller historien os}

mi, samfund og politik. Den moderne historievidenskab har på afgørende vis frigjort sig herfra. ${ }^{19}$ Dens genstandsområde er, takket være sociologien, udvidet betydeligt. Opmærksomheden vies nu såvel grupper og institutioner som også udforskningen af sociale systemers forandring og af samfundsmæessige beslutningsprocesser, hvis betydning rækker frem til i dag. Og her har historievidenskaben kunnet drage nytte af, at også sociologien har ændret sig, at den har opgivet sin "historieblindhed" (udpræget i den anglo-amerikanske forskning) og i stadig højere grad tager hensyn til den historiske faktor.

Således er der opstået en »historisk samfundsvidenskab« som en syntese af historie og sociologi, en syntese, som man for $\emptyset$ vrigt allerede har haft tidligere; man kan blot tænke på Emile Durkheim og Max Weber. Man taler derfor i dag til dels om historievidenskabens genstand som »samfundshistorie«, der ikke blot er en deldisciplin, men »konstitueres af de tre ligeberettigede dimensioner: økonomi, politik og kultur ${ }^{20}{ }^{20}$ \#istorisk samfundsvidenskab«, siger historikeren Jürgen Kocka,

betyder en historievidenskab, der ikke primært udforsker begivenheder, personer, intentioner og handlinger, men først og fremmest strukturer og processer som betingelser for og følger af begivenheder, beslutninger og handlinger; strukturer og processer, som ikke var fuldt bevidste for de besluttende og handlende personer, som disse ikke eller kun delvist eller forvrænget kunne erfare; strukturer og processer, som ganske vist har bestemt eller påvirket begivenhederne, handlingerne og erfaringerne, men som ikke er identisk med disse. Den historiske samfundsvidenskab drager dermed - og det er den mest almene bestemmelse af den - konsekvensen af den ofte begrundede indsigt, at historien ikke er identisk med det, som menneskene gensidigt intenderer eller erfarer, men at omgivelserne i mindst lige så høj grad skaber menneskene som menneskene omgivelserne, og at historien derfor ikke lader sig begribe tilstrækkeligt som en sammenhæng af begivenheder, beslutninger, erfaringer og handlinger. ${ }^{21}$

Med denne arbejdsmåde forlades den traditionelle hermeneutisk-forstående metode til fordel for analytiske fremgangsmåder, der forudsætter en eksplicit teorianvendelse og kvantitative metoder, som sociologien kender dem. ${ }^{22}$

Det betyder naturligvis ikke, at der ikke findes kritiske spørgsmål, som her fornemmer en ensidig betragtningsmåde, og som derfor har ført 


\section{Kurt Rudolph}

til videre historiografisk arbejde. Således den historisk-antropologiske forskning, der har modtaget inspiration fra antropologi eller etnologi og etologi (adfærdsforskning). ${ }^{23}$ Den såkaldte »hverdagsforskning « har sin Sitz im Leben her. Rammerne for den historiske samfundsvidenskab sprænges dog ikke afgørende hermed, således som J. Kocka med rette har fastslået. ${ }^{24}$ Hjemmehørende på dette område er også den i Frankrig udviklede "mentalitetsforskning «, ligesom i det hele taget værkerne fra de store "Annales«-historikere: Marc Bloch, Lucien Febvre, Fernand Braudel, Philippe Ariès. At man har forladt den traditionelle, strengt kronologisk orienterede historievidenskab til fordel for en omfattende analyse af de »lange tidsrum« (longûe durée), der bestræber sig for at nå ud i de fjerneste afkroge af det menneskelige liv, har ført til en helt ny betragtning af kategorierne rum og tid historisk anskuet, til en histoire totale. $^{25}$ I disse arbejder har også begrebet "struktur « fået hjemme. ${ }^{26}$ Dermed menes »en realitet, som tiden kun i ringe omfang slider på og bevæger fremad «. ${ }^{27}$ Om disse "strukturer « virkelig kan påvises historisk uforandrede, altså repræsenterer noget næsten overtidsligt, er et omdiskuteret spørgsmål, der endnu ikke er afklaret. Sikkert er det, at en vekselvirkning mellem »korte tidsforløb« (temps court), »begivenheder« og »lange tidsrum« er indvæevet i den menneskelige livstid. Det materiale, der her kan benyttes som »kilde«, er som antydet meget vidtløftigt: ikke kun tekster, men alle dokumenter og efterretninger, som på en eller anden måde kan belyse den menneskelige side af historien - som hos $\mathrm{L}$. Febvre, for hvem historien som videnskaben om mennesket er videnskaben om den menneskelige fortid. ${ }^{28}$

Lad os forlade denne nye side af historievidenskaben og kaste blikket på den anden, teoridiskussionen. Som allerede antydet står den i snæver sammenhæng med inddragelsen $i$ historiefaget af samfundsvidenskabelige forskningsmetoder. På begge områder har behovet for gensidig udveksling været stort. »Teoriløs historie og historieløs sociologi ${ }^{29}$ gjaldt som gensidige beskyldninger, der har ført til en vis udligning. ${ }^{30}$ Analyser af historisk-sociale processer har brug for en refleksion, der rækker ud over det blotte faktamateriale. Mangfoldigheden i det materiale, der må inddrages fra $\emptyset$ konomi, sociologi, politik, litteratur eller sprog og kultur, kræver en nærmere forestilling om materialets relevans, 


\section{Hvad religion er, fortaller historien os}

betydning og udsagnskraft. Forholdet mellem økonomi, samfund og politik må bindes analytisk sammen i en teori. Frem for alt var det omsider på tide at betragte historikeren selv som en del af historien: hans baggrund, uddannelse og samfundsmæssige stilling, men også de ledende ideer $\mathrm{i}$ hans forskning og ikke mindst erkendelsesinteressen bag den. Derfor er litteraturen om teorier i historievidenskaben vokset enormt. Der er publiceret bud på en ny »historik«, der naturligvis adskiller sig meget fra Droysens fra 1857, men som dog fortsætter dennes tradition for selvrefleksion $\mathrm{i}$ forhold til det historiske håndværk. ${ }^{31}$ Teoriudvikling og teoribrug $\mathrm{i}$ historievidenskaben gælder som en »forøgelse af dens videnskabelige rationalitet ${ }^{32}$

Den historiske erkendelses logik, dens egenart, dens formål, den historiske videns og dermed selve historievidenskabens placering og betydning i samfundet før og nu, er i stigende grad blevet underkastet analyse, således at den traditionelle teorifjendtlighed i historievidenskaben $\mathrm{i}$ dag i vid udstrækning er opgivet. Naturligvis har man i mellemtiden til gengæld kunnet registrere en vis teoritræthed, men selve den impuls, som diskussionen af historievidenskabens metodik og almene stilling har givet faget, har uden tvivl været frugtbar, også for den konkrete historieskrivning. Resultatet er i hvert fald blevet erkendelsen af, at der ikke findes en historieskrivning uden teori, en erkendelse, som allerede historievidenskaben i det 19. århundrede glimtvis nåede (f.eks. hos J. G. Droysen), men blot ikke altid tog til efterretning. En god sammenfatning af »teorier i historievidenskaben « gav Joseph Meran i 1985. Hos ham finder man på forbilledlig vis en analyse af det brede spektrum af åben eller skjult teorianvendelse i den historiske forskning. Det grundlæggende synspunkt er: "Hvis historien vil være en videnskab, så må den selv udforme og anvende sine teorier ${ }^{33}$ En konsekvent følge af denne grundsætning er en »videnskabeliggørelse« af historieskrivningen såvel som af historievidenskaben som sådan.

Den nye teoretiske bevidsthed - som ikke alle historikere hilser velkommen, men som de imidlertid er tvunget til at acceptere - har i sine diskussioner behandlet en lang række temaer, som til dels repræsenterer gamle uløste problemer inden for historievidenskaben. Eftersom de ikke alle kan præsenteres nærmere, må jeg gribe til nogle publikatio- 
ner, som formidler et fint udsnit deraf. Der er tale om følgende seks bind Theorie der Geschichte. Beiträge zur Historik, der udkom på dtvVerlag i München mellem 1977 og 1990:

-Objektivität und Parteilichkeit in der Geschichtswissenschaft (udgivet af R. Koselleck, W. J. Mommsen og J. Rüsen, 1977).

- Historische Prozesse (udgivet af K. G. Faber og Chr. Meier, 1978).

- Theorie und Erzählung in der Geschichte (udgivet af J. Kocka og Th. Nipperdey, 1979).

-Formen der Geschichtsschreibung (udgivet af R. Koselleck, H. Luz og J. Rüsen, 1982).

- Historische Methode (udgivet af Chr. Meier og J. Rüsen, 1988).

- Teil und Ganzes (udgivet af K. Acham og W. Schulze, 1990).

Alle disse bind med forskellige bidrag fremlægger et bredt - og ikke kun tysksproget - spektrum af den moderne historievidenskab. Det er ikke altid, man kan se løsningerne, men der er gode forsøg på at analysere de vigtigste grundproblemer og på at skabe forståelse for de forskellige standpunkter. Således gennemarbejdes temaet om objektivitet og subjektivitet ("partiskhed «) i en dialog med det marxistiske standpunkt, med det resultat, at begge faktorer lader sig formidle igennem den reflekterende fornuft. ${ }^{34} \mathrm{Jeg}$ ville sige, at det må være muligt at opnå en relativ objektivitet $\mathrm{i}$ historievidenskaben, idet en total eliminering af den subjektive faktor med en tabula rasa eller en fuldstændig neutralitet som resultat kun vanskeligt lader sig realisere. Værdidommene, og om dem drejer det sig ofte, skinner altid igennem og er klart erkendelige for historikeren ved bestemte epoker (f.eks. med henblik på nazitiden i Tyskland). ${ }^{35}$

Endnu et tema er historieskrivningen: Her er narrativitetens ekstreme position som kontinuitetsskabende faktor ikke alment accepteret, selv om en metakritik af den historiske fornuft vil være tilbøjelig dertil. $^{36} \mathrm{~J}$. Rüsen har beskrevet de forskellige former for historieskrivning og har analyseret deres forskellige værdi: traditionel eksemplarisk, kritisk og genetisk fortælling. ${ }^{37}$

Forholdet mellem »forståelse « og »forklaring « $\mathrm{i}$ historievidenskaben er et ofte debatteret problem. Om dette problem er der i de senere år blevet ført en livlig diskussion, udløst netop af introduktionen af den 


\section{Hvad religion er, fortaller historien os}

analytiske, sociologiske metode $\mathrm{i}$ historievidenskaben. Forståelsens metode, som især er blevet taget $\mathrm{i}$ anvendelse i tysk historievidenskab siden Droysen og Dilthey, er blevet opstillet som en konform strategi for historievidenskaben over for naturvidenskaben, der er forpligtet på »forklaringen«, dvs. kausalsammenhængene. Denne metodiske dikotomi med dens omhyggelige skelnen mellem ånds- eller kulturvidenskaber over for naturvidenskaber er i dag i vid udstrækning overvundet, og det netop som en følge af debatterne $i$ den moderne historievidenskab. ${ }^{38}$ Den historiske samfundsvidenskab eller samfundshistorien arbejder med begge strategier: både med "forståelsen « som tilgang til et historisk sagforholds »betydning « og med dets kausale forklaring; kun til sammen giver de et nogenlunde autentisk billede af det historiske sagforhold, og begge hører derfor med i ethvert historisk arbejde.

I et helt nyt studie er dette tema på ny blevet udførligt behandlet. ${ }^{39}$ Resultatet af dette studie er, at problematikken forklaring/forståelse ikke hører til de centrale problemer, der synes værd at gå i en intensiv metodisk og metodologisk konfrontation med for historikeren af i dag:

Hverken forklarings- eller forståelsesbegrebet eller spørgsmålet om det rigtige forhold mellem en forklarende og en forstående fremgangsmåde $i$ historieskrivningen spiller nogen nævneværdig rolle i diskussionerne blandt de historikere, jeg er kommet ind på. I stedet er det andre problemer, der står i forgrunden for interessen: spørgsmålet om hvilke temaområder en moderne historieskrivning skal beskæftige sig med, spørgsmålet om hvilken grad af teoriorientering og -anvendelse, der er passende og heuristisk frugtbar, spørgsmålet om historikeren skal fæste øjet ved strukturer og langvarige udviklingslinier eller snarere ved begivenheder, og andre spørgsmål...40

Dog består der vedblivende forskelle mellem f.eks. en H.-U. Wehler, der som teori- og strukturorienteret historiker tillægger den historiske fortælling ringe værdi, og en Golo Mann, der netop betragter det narrative som helt afgørende. "Hos begge findes forståelse kun i betydningen 'at forstå noget' og som resultat af forklaringer, ikke i betydningen af en indfølende forståelse «. Hos begge ses derimod forklaringer i stort tal og i stor mangfoldighed; ved siden af den funktionelle forklaring som hos Wehler står den psykologiske som hos Mann; begge arbejder desuden i 
større (Wehler) eller mindre (Mann) udstrækning med genetiske forklaringer. ${ }^{41}$

Til slut skal også diskussionen om »del og helhed « berøres. Det er en diskussion, der drejer sig om makro- og mikrohistorie, om det enestående og singulære over for det generelle og almene, om individualisme og kollektivisme - og som derved ikke viger tilbage for at søge løsningsmodeller på det biologiske og fysiske område; som man ser er den moderne historievidenskab åben til mange sider, også til naturvidenskabens. Det der allerede kom til syne i forbindelse med, at man forlod det klassiske individualitetsprincip og dyrkelsen af forståelsen, fortsætter i diskussionen om den såkaldte hermeneutiske cirkel, der forener del og helhed. ${ }^{42}$ Her har "sammenligningen « (komparationen), som netop stiller sig problemet om det "regionale« over for det "universelle«, fået forøget betydning. Den moderne historievidenskab integrerer komparationen på regionalt og universelt plan som heuristisk middel i en forklaring. Det gjorde i øvrigt allerede Max Weber på storartet måde i sin kombination af historie og sociologi. For religionsvidenskaben er der meget at hente her. ${ }^{43}$

Jeg må udelade historievidenskabens betydning for vort historiebillede i dag og den konsekvens, der ligger heri for tydningen af nutiden. Også dette eksistentielle aspekt står ellers helt i fokus for historikerne: deres stilling og engagement i politik, samfund og universitet giver sig mangfoldige udslag.

Diskussionerne om den historiske erkendelses værdifrihed og værdiafhængighed har ganske vist ikke ført til det resultat, at man i enhver henseende må tilskrive historievidenskabens erkendelsesprodukter værdifrihed, men de har gjort det tydeligt, at religiøs tydning og videnskabelig erkendelse hverken fuldstændigt eller omkostningsfrit er kompatible. Sandheds- og betydningsspørgsmålet er igen åbent i historiekulturen. Historievidenskaben kan ikke unddrage sig disse spørgsmål, hvis den vil forstå sig selv som en del af nutidens historiekultur, men lige så lidt kan der plausibelt tænkes og debatteres om sandhed og betydning på alle historiekulturens felter, uden at man samtidig berører den videnskabelige historiske erkendelses resultater og grænser. ${ }^{44}$ 


\section{Hvad religion er, fortæller historien os}

Dertil hører imidlertid også, således som f.eks. W. Mommsen eller J. Rüsen har tematiseret det, den ideologi- eller normkritiske funktion, som den historievidenskabelige erkendelse, direkte såvel som indirekte, har fået. ${ }^{45}$

\section{III}

Hvis vi til slut spørger, hvilket udbytte den nutidige religionsvidenskab kan hente hos den moderne historievidenskab, så er der tale om en hel række impulser, der i øvrigt kan støtte sig på ændringer inden for det religionsvidenskabelige fag selv. Dertil hører frem for alt den samfundsvidenskabelige orientering og den teoretiske interesse.

Først til samfundsvidenskaben. Her har religionsvidenskaben trods ældre ansatser i religionssociologien et udækket behov, der opstod derved, at ansatserne hos Marx, Durkheim og Weber af J. Wach og G. Mensching blev bragt ind i et religionsvidenskabeligt farvand, som udviskede den egentlige sociologiske ansats til fordel for et emotionelt religionskoncept orienteret mod individet. Når historikeren Richard van Dülmen nu har rettet en skarp kritik mod den tyske religionsvidenskab, tager han netop sigte på denne retning, der ikke har forstået religion som en social kendsgerning og dermed har udelukket en væsentlig side af fænomenet. Hvis nemlig religionsforskningen tager udgangspunkt i den overbevisning

at religion realiseres $i$ historie og samfund, er en empirisk størrelse, at religion altså er et socialt fænomen, der er begrundet i menneskers, gruppers og samfunds sociale handlinger, så kommer stort set alle kendte definitioner til kort. Religionshistoriske definitionsfors $\emptyset \mathrm{g}$ er enten så forskellige, at de til dels gensidigt udelukker hinanden, eller så almene og formale, at de viser sig utilstrækkelige ved en udforskning af konkrete religiøse institutioner, reaktionsmåder eller symbolsystemer i historien. Det er derfor forståeligt, hvis historievidenskaben undviger et definitionsfors $\emptyset \mathrm{g}$ og orienterer sig efter dagligsprogets begreber. For $\mathrm{i}$ en forskningsmæsig praksis duer hverken Ottos almene bestemmelse af religion som erfaring af det hellige eller Menschings af religion som et oplevelsesmæssigt møde med en hellig virkelighed og en dertil svarende menneskelig handlen. Det er åbenbart, at begge orienterer sig efter en ahistorisk tænkende fænomenologi. ${ }^{46}$ 
Det nytter ikke noget at orientere sig efter læresystemer, og da slet ikke religionsstifternes eller teologernes. Man kan ikke nøjes med de generelle betegnelser på verdensreligionerne, eftersom disse blot betyder en typologisering af ydre former. Forskningen må i stedet erfare og analysere de til enhver tid foreliggende konkrete tilstande og forandringer $\mathrm{i}$ de faktiske religiøse forhold $\mathrm{i}$ et samfund. Den religionsvidenskabelige forskning mangler en kobling til religionens reelle udformning i hverdagslivet, i den samfundsmæssige praksis; forbindelsen mellem ideer, interesser og politisk-sociale bevægelser er i religionsvidenskaben indtil nu kun blevet forfulgt rent sporadisk.

Hvad religion, religiøs lære og religiøs symbolik er, hvilken funktion de udøver $\mathrm{i}$ samfundet, og omvendt, hvilken rolle der tilkommer dem $\mathrm{i}$ historien, $\mathrm{i}$ historiske og sociale processer - hvis vi dermed $\mathrm{i}$ almindelighed vil beskrive en religionsforsknings opgaver - det lader sig ikke begribe med et religionsbegreb og en religionstypologi, der er hentet uden for historisk tid og samfundsmæssigt rum, og som er orienteret mod en religions i sidste ende metahistoriske »væsen«. Religionsfænomenologien og den traditionelle kirkehistorie åbner derfor ingen perspektiver for en historisk analyse af religion. Religion kan ikke tænkes uden for menneskets sociale handlen og dets samfund, og i overensstemmelse hermed kan den også kun begribes ud fra den pågældende samfundsformations kontekst og ud fra de forudsætninger, i hvilken den er opstået eller i hvilken den har fået social og politisk betydning. Hvis den almene religionsvidenskab kun opererer med religion som en størrelse, der er givet $\mathrm{i}$ og med menneskets væsen, så kan den kun begribe religiøse fænomener som religiøse, som hellige og numinøse, ikke derimod deres sociale rolle og karakter, deres centrale funktion som middel til verdensorientering $\mathrm{i}$ en samfundsmæessig proces. En historisk religionsforskning tematiserer religion som et socialt fænomen og analyserer religion på baggrund af de sociale interesser, der bærer den. Netop disse interesser kan den også takke for sin specifikke form. En ny typologi kan begynde her. ${ }^{47}$

Den dialektiske sammenfletning af religion og samfund, som ofte kun på en meget kunstig måde kan vikles løs fra hinanden, fører til den opfattelse, at der ikke gives uafhængige religiøse konstanter i historien:

Religion, religiøsitet eller religiøse fænomener lader sig altså generelt ikke indholdsmæssigt og formelt bestemme ud fra sig selv, men kan kun beskrives og analyseres adækvat inden for rammerne af den sociale ordning, hvori de for mennesker 


\section{Hvad religion er, fortaller historien os}

og samfund er virkelighed som religiøse institutioner og samfundsmæssig bevidsthed. $^{48}$

Igen og igen vil det ved det praktiske arbejde med dette objekt vise sig, at religiøse forhold - for så vidt som de overhovedet spiller en rolle og tematiseres - har etableret sig i menneskers sociale handlen: som en faktor, der er bestemt deraf, eller som en motiverende, aktiverende kraft. Som facit kan man uden tøven sige, at religionsforskning uden historie er blind, ligesom religionsforskning uden samfundsvidenskabelige eller sociologiske analyser er tom.

Dermed er teorisektoren allerede omtalt: Det er nødvendigt med et smidigt religionsbegreb, der støtter sig på den empiriske religionsforskning og ikke knytter sig til lære, dogmer osv., som ofte kun er kendt af en lille kreds af specialister. I de troendes praktiske liv er det ofte helt andre, meget mere konkrete anliggender, der spiller en rolle. Levende religion er under denne synsvinkel kun forståelig som en konkret magt. Enhver religiøs erfaring er indlejret i en social, kulturel, historisk verden, og den kan ikke abstraheres fra denne, endsige tages som udgangspunkt for religion som sådan: det er en ahistorisk fremgangsmåde, som religionsvidenskaben alt for længe har forskrevet sig til. Det kan derfor hilses velkomment, når $\mathrm{H}$. G. Kippenberg i et stort anlagt studie har forsøgt at forstå de nærorientalske frelsesreligioner ud fra deres konkrete historisk-sociale kontekst, nemlig det antikke bymiljø, og derudfra har forsøgt at forklare ændringen i dem. ${ }^{49}$ Den traditionelle opdeling mellem individ og samfund, begivenhed og struktur, verdensbillede og etos, kultur og religion, skal også overvindes i religionsvidenskaben. Derfor er det nødvendigt, at man opgiver »at forstå religiøse handlingers betydning ud fra det deltagende subjekts intention og hensigter $o g$ at definere religion som en individuel transcendenserfaring $\ll_{.}{ }^{50}$ Der er brug for en "pragmatisk vending « i religionsvidenskaben. Menneskenes handlinger skal undersøges ud fra, hvorledes de gyldighedskrav, som rejses af de religiøse verdensbilleder eller systemer, anvendes og samtidig forvandles i en politisk-samfundsmæssig praksis. Når religioner kan influere på, ja begrunde, en samfundsmæssig praksis, så må det også være muligt at gøre rede for, hvorledes den deraf afledte handlen fører 
til forandring af den religiøse ideologi, uafhængigt af den enkeltes tro. Spørgsmålet om hvorledes den religiøse forestillingsverden forandres i den samfundsmæssige praksis, er fortsat en gåde, som den traditionelle »ide- og bevidsthedshistorie« ikke har kunnet afsløre.

Der er ikke tid til at komme ind på yderligere impulser. Debatten om forklaring/forståelse, som inden for religionsvidenskaben længe er blevet ført i først Diltheys og siden Gadamers kølvand, kan for historievidenskabens vedkommende betragtes som et overstået stadium. Det har jeg selv allerede tidligere fastslået. ${ }^{51}$ Også for religionsvidenskaben gælder, at der ikke gives forståelse uden forklaring - og omvendt. Forståelse som »indlevelse« (Einfühlung) er ingen videnskabelig metode, allerhøjst en intuitionskunst, som ikke har nogen videnskabelig udsagnskraft, højst en religiøs. Man kan betragte den som et heuristisk princip, men den kan ikke stå alene; den har brug for en videnskabelig forklaring på kendsgerningen, på dens hvorfra og dens bestemmende kontekst. Derfor er den bekendte $" \mathrm{H}$-O-model« helt igennem et forbillede for en videnskabelig forklaring inden for de historiske og filologiske videnskaber. ${ }^{52}$

Et vigtigt resultat af den historiske religionsforskning er pluralismen i religionssamfundene, der ofte skjules under hypostaserende typologier. Ingen religion er en lukket størrelse, hverken indadtil eller udadtil. Den såkaldte kristendom består f.eks. af en mangfoldighed af kirker, som i deres konkrete udformning er bestemt af rum og tid. Sociologisk betragtet kan vi konstatere en meget differentieret lagdeling inden for de enkelte "kristendomme«, som hver især sidder inde med sin forståelse, sin specielle tilegnelse af overleveringen (eller ikke gør det). Horisontalt og vertikalt er alle de formationer, der benævnes »religioner«, pluralistiske symbol- og handlingssystemer. Betydningen af dette faktum for udformningen af en almen religionsteori er der hidtil blevet taget for lidt hensyn til.

Når man i dag betragter jordkloden under en religionsvidenskabelig synsvinkel, må man se i øjnene, at det religiøse billede i stigende grad fremviser en ydre pluralisme, en gensidig optagelse af forbindelser, som ikke længere er bestemt af apologetisk polemik. Religionsvidenskaben kaster lys over denne proces, som vi dagligt kan registrere i vor egen 


\section{Hvad religion er, fortæller historien os}

livsverden, eller som vi ved rejser i fremmede lande kan stifte bekendtskab med. Ikke som middel til at tage aktivt del deri, som de religiøse repræsentanter selv, men som interesserede iagttagere af en forandring af verdenshistorisk betydning.

Vi kender netop fra religionshistorien dannelsen af »økumeniske« religionsprovinser, i hvilke mange religioner og trosmåder mødes (f.eks. i den gamle Middelhavsverden, som vi er så fortrolige med) og har derigennem en historisk paratviden, der gør, at vi ikke behøver betragte den nutidige proces som en enestående begivenhed, selv om der nu er tale om en verdensomspændende proces. Den moderne historievidenskab taler om, at en histories mening tjener til at »forøge identiteten hos det subjekt, meningen drejer sig om«, og udstrækker man det omhandlede subjekt ud til den yderste grænse for historisk erfaring, får man i sit synsfelt menneskeslægten som sådan, der befinder sig »i en universel evolutionsproces «. ${ }^{53}$ Anvendt på religionsvidenskaben vil det sige, at den nutidige religionsmødeproces $\mathrm{i}$ sin konkrete institutionelle og individuelle fremtoning, hvis man skal fremstille dens historie i en narrativ form, på en måde vil blive den moderne menneskeheds historie betragtet ud fra en virkelig almen religionshistorie - noget man hidtil kun har haft i ansatser og meget ufuldkomment, eftersom de religiøse provinser eller kulturer endnu er alt for isolerede til, at en virkelig udveksling kan finde sted. Som fremtidsvision bliver erkendelsen, også i historisk forstand, af den verdenshistoriske proces, som det nutidige religionsmøde repræsenterer, en opgave for religionsvidenskaben i international målestok, og den vil derved kunne vende sig mod en del af den moderne verden, som i stigende grad er prisgivet tilintetgørelsen.

\section{Noter}

1. „Was Religion ist, sagt uns die Geschichte: Zum Verhältnis von Geschichtswissenschaft und Religionswissenschaft «. Foredrag på symposiet »Methodology in the Study of Religion «, Aarhus Universitet, den 22. juni 1992. Oversat af Per Ingesman.

2. Wilhelm Dilthey, Gesammelte Schriften, Band 8, 5. Ausgabe, Stuttgart \& Göttingen 1962, 226.

3. »Die Melodie unseres Lebens ist bedingt durch die begleitenden Stimmen der Vergangenheit. Von der Qual des Augenblicks und der Flüchtigheit jeder Freude befreit 


\section{Kurt Rudolph}

sich der Mensch nur durch Hingabe an die großen objektiven Gewalten, welche die Geschichte erzeugt hat «. Smst.

4. "Das Messer ... des historischen Relativismus, welches alles Metaphysik und Religion gleichsam zerschnitten hat, muß auch die Heilung herbeiführen«. Smst., 234; det drejer sig om en tale fra 1904.

5. Citeret efter Bruchstücke der unendlichen Menschheit, hrsg. K. Nowak, Berlin 1984, 51.

6. Jf. det foredrag med titlen »Inwieweit ist der Begriff 'Religion' eurozentrisch? «, som jeg holdt på den internationale religionshistorikerkongres i Rom i 1990 (under trykning).

7. Jf. nu det udvalg af mine arbejder, der foreligger i Geschichte und Probleme der Religionswissenschaft, (Studies in the History of Religions. NUMEN Bookseries, vol. 53), Leiden 1992, især første del: »Theorie und Methodologie «.

8. Jf. hertil mit bidrag "Texte als religionswissenschaftliche Quellen«, i: H. Zinser (Hrsg.), Religionswissenschaft. Eine Einführung, Berlin 1988, 38-54.

9. P. Szondi, »Über philologische Erkenntnis«, i: Hölderlinstudien, Frankfurt a.M. 1967 (3. udgave 1977), oprindelig trykt i Die Neue Rundschau 73. årg. hæfte 1, 1962, 146165. Jeg har benyttet tanken i mit bidrag "The Foundations of the History of Religions and Its Future Task«, i: J. H. Kitagawa (ed.), The History of Religions, Retrospect and Prospect, New York/London 1980, 105-120, se især s. $106 \mathrm{ff}$.

10. Jf. H. Flashar, K. Gründer, A. Horstmann (Hrsg.), Philologie und Hermeneutik im 19. Jahrhundert, Göttingen 1979, 166.

11. Verhandelungen des 2. Internationalen Kongresses für Allgemeine Religionsgeschichte, Basel (1904), Basel 1905, 75. Jeg har tidligere citeret udtalelsen i Geschichte und Probleme der Religionswissenschaft, $68 \mathrm{f}$.

12. Jf. H. Flashar m.fl., Philologie und Hermeneutik im 19. Jahrhundert, $240 \mathrm{ff}, 260 \mathrm{ff}$.

13. Jf. min korte fremstilling i Geschichte und Probleme der Religionswissenschaft, 412420.

14. "... so zu schreiben, wie man sonst ein Kapitel der allgemeinen Religionsgeschichte schreibt... Man kann sagen, daß die religionsgeschichtliche Behandlung hier nichts weiter bedeutet als eine realgeschichtliche«. William Wrede, "Das theologische Studium und die Religionsgeschichte«, i: William Wrede, Vorträge und Studien, Tübingen 1907, 64-83; citat fra s. 65.

15. "Die religionsgeschichtliche Methode ist nur Anwendung der allgemeingeschichtlichen auf den besonderen Gegenstand«. Wilhelm Dilthey, Gesammelte Schriften, Band 8, 28. Jf. dertil også K. Oehler, "Dilthey und die klassische Philologie«, i: H. Flashar m.fl., Philologie und Herneneutik im 19. Jahrhundert, 181-198.

16. Lærestolen i religionshistorie ved Karl-Marx-Universität Leipzig (nu igen: Universität Leipzig) blev efter opløsningen af det filosofiske fakultet i 1968 indordnet $i$ den nyoprettede sektion for historie. Om dette begivenhedsforløb og dets konsekvenser 


\section{Hvad religion er, fortaller historien os}

se nu mine bemærkninger i Geschichte und Probleme der Religionswissenschaft, VIII ff., $337 \mathrm{ff}$.

17. Således Karl Löwith, Von Hegel zu Nietzsche, 5. Ausgabe, Stuttgart 1964, 75. Jf. også Wolfgang J. Mommsen, Die Geschichtswissenschaft jenseits des Historismus, Düsseldorf 1971, 2. Ausgabe, 1972, 14. Om begrebets og problemets historie se nu Annette Wittkau, Historismus, Göttingen 1992.

18. Jf. blandt andet Karl Lamprecht, Altemative zu Ranke. Schriften zur Geschichtstheorie, Leipzig 1988; G.G. Iggers, The German Conception of History, Middleton (Connecticut) 1983, 197 ff.; H.-J. Steinberg, »Karl Lamprecht«, i: H.-U. Wehler, Deutsche Historiker, I, Göttingen 1971, 58 ff. [Historikeren Karl Lamprecht (1856-1915) stod med sin sociale og økonomiske historieskrivning som en ener over for sin samtids overvejende politisk orienterede historikere. (oversætters anmærkning)]

19. Jf. W. J. Mommsen, Die Geschichtswissenschaft jenseits des Historismus; H.-U. Wehler (Hrsg.), Geschichte und Soziologie, Köln 1984.

20. H.-U. Wehler i Historische Zeitschrift, 225, 1977, 364.

21. »Historische Sozialwissenschaft meint eine Geschichtswissenschaft, die nicht primär Ereignisse, Personen, Intentionen und Handlungen erforscht, sondern vor allem Strukturen und Prozesse als Bedingungen und Folge von Ereignissen, Entscheidungen und Handlungen; Strukturen und Prozesse also, die den entscheidenden und handelnden Personen nicht voll bewußt waren, von ihnen nicht oder nur z.T. oder verzerrt erfahren wurden; Strukturen und Prozesse, die die Ereignisse, Handlungen und Erfahrungen zwar bestimmen oder beeinflussen aber nicht in diesen aufgehen. Historische Sozialwissenschaft zieht damit, und das ist ihre allgemeinste Bestimmung die Konsequenz aus der vielfach begründbaren Einsicht, daß die Geschichte nicht in dem aufgeht, was die Menschen wechselseitig intendieren oder auch erfahren, daß die Umstände mindestens so sehr die Menschen wie die Menschen die Umstände machen, daß sich die Geschichte nicht zureichend als Zusammenhang von Ereignissen, Entscheidungen, Erfahrungen und Handlungen begreifen läßt«. J. Kocka i: H. Süssmuth (Hrsg.), Historische Anthropologie, Göttingen 1984, 73; jf. også W. J. Mommsen, "Geschichte als Historische Sozialwissenschaft«, i: Pietro Rossi (Hrsg.), Theorie der modemen Geschichtsschreibung, Frankfurt a.M. 1987, 107 ff.

22. Jf. Kocka, smst., 74.

23. Se oversigten hos H. Süssmuth, Historische Anthropologie; A. Nitschke, Historische Verhaltensforschung, Stuttgart 1981.

24. Anf.arb., 81.

25. Jf. F. Furet, "Die Methoden der Sozialwissenschaften in der Geschichtswissenschaft und die »historie totale««, i: P. Rossi (Hrsg.), Theorie der modemen Geschichtsschreibung, 147-172; D. Groh, Anthropologische Dimensionen der Geschichte, Frankfurt a.M. 1992, 117-147 (med bibliografi); Ph. Ariès, Zeit und Geschichte, Frankfurt a.M. 1988, især $234-250$.

26. Jf. F. Braudel hos H.-U. Wehler, Geschichte und Soziologie, $194 \mathrm{f}$. 
27. Braudel, anf.arb. For en kritik jf. f.eks. D. Groh, Anthropologische Dimensionen der Geschichte, $138 \mathrm{ff}$.

28. Lucien Febvre, Das Gewissen des Historikers, Frankfurt a.M. 1990 (fransk originaludg. Paris 1953, 2. udg. 1957), $17 \mathrm{f}$.

29. Således H. P. Dreitzel hos Wehler, Geschichte und Soziologie, $27 \mathrm{ff}$.

30. Jf. ogs̊̊ Mommsen, Geschichtswissenschaft, 39 ff.; Wehler, Geschichte und Soziologie, $14 \mathrm{ff}$.

31. Jf. Jörn Rüsens »Grundzüge einer Historik « i tre dele: Historische Vernunft, Göttingen 1983; Rekonstruktion der Vergangenheit, Göttingen 1986; Lebendige Geschichte, Göttingen 1989.

32. J. Rüsen, Zeit und Sinn, Frankfurt a.M. 1990, 17.

33. J. Meran, Theorien in der Geschichtswissenschaft, (Kritische Studien zur Geschichtswissenschaft 66), Göttingen 1985, 163. Jf. også J. Rüsen i: Theorie der Geschichte, bd. 6, München 1990, $308 \mathrm{ff}$.

34. Om den relative objektivitet i historievidenskaben se Maurice Mandelbaum, The Anatomy of Historical Knowledge, 2. ed., Baltimore 1977, 45 ff.; jf. også J. Rüsen i: Theorie der Geschichte, bd. 6, München 1990, $308 \mathrm{ff}$.

35. Dette er blevet tydeligt $\mathrm{i}$ den nye tyske »Historikerstreit « (1986-88) omkring vurderingen af de nazistiske krigsforbrydelser.

36. Jf. H. M. Baumgartner, Kontinuität und Geschichte, Frankfurt a.M. 1972, især 248 ff.; samme i: J. Rüsen, Historische Objektivität, $48 \mathrm{ff}$. For en kritik se Mommsen hos Rossi, Theorie der modernen Geschichtsschreibung, $132 \mathrm{ff}$., især $138 \mathrm{f}$.

37. J. Rüsen, Zeit und Sinn, 84 ff. og 153 ff.; jf. også Mommsen hos Rossi, Theorie der modemen Geschichtsschreibung, $120 \mathrm{f}$.

38. Jf. Mommsen og U. Muhlack i: Theorie der Geschichte, bd. 5, 1988, 200 ff. og 227 ff.; meget klart demonstreret af G. Patzig, Tatsachen, Normen, Sätze, Stuttgart 1980, $45 \mathrm{ff}$.

39. Thomas Haussmann, Erklären und Verstehen: Zur Theorie und Pragmatik der Geschichtswissenschaft. Mit einer Fallstudie über die Geschichtsschreibung zum deutschen Kaiserreich 1871-1918, Frankfurt a.M. 1991.

40. »Weder der Erklärungs- noch der Verstehensbegriff noch die Frage nach dem richtigen Verhältnis von erklärendem und verstehendem Vorgehen in der $\mathrm{Ge}$ schichtsschreibung spielen in den Diskussionen unter Historikern, auf die ich eingegangen bin, eine nennenswerte Rolle. Statt dessen sind es andere Probleme, die im Vordergrund des Interesses stehen: die Frage nach den Themenfeldern etwa, mit denen sich eine moderne Geschichtsschreibung auseinandersetzen sollte, die Frage nach dem $\mathrm{Maß}$ an Theorieorientierung und Verwendung, das angemessen und heuristisch fruchtbar ist, die Frage, ob der Historiker sein Augenmerk auf Strukturen und langfristige Entwicklungslinien oder eher auf Ereignisse legen sollte, und andre Fragen...«. Smst., 319 f. 


\section{Hvad religion er, fortæller historien os}

41. Smst., $320 \mathrm{f}$. Paul Veyne maner til forsigtighed ved kausalgenetiske afledninger: Geschichtsschreibung - und was sie nicht ist, Frankfurt a.M. 1990, 104 ff. (fransk originaludg.: Comment on écrit l'histoire, Paris 1971), men også over for forståelsen, som for ham er en »retrospektiv illusion« (128 ff.). Jf. også P. Gardiner, The Nature of Historical Explanation, Oxford 1961, 3. ed. 1980.

42. E. Ströker, «Über die mehrfache Bedeutung der Rede von Ganzen und Teilen«, i: Theorie der Geschichte, bd. 6, 1990, 278-298.

43. Jf. mine udredninger herom i Geschichte und Probleme der Religionswissenschaft, 51 ff., $56 \mathrm{f}$, med henvisning til Th. Schieder, Geschichte als Wissenschaft, München $1965,158 \mathrm{ff} ., 187 \mathrm{ff}$.

44. $\gg$ Die Debatten über die Wertfreiheit und Wertgebundenheit der historischen Erkenntnis haben zwar nicht zu dem Resultat geführt, daß man den Erkenntnisleistungen der Geschichtswissenschaft in jeder Hinsicht Wertfreiheit zubilligen muß, aber sie haben deutlich gemacht, daß religiöse Sinngebung und wissenschaftliche Erkenntnis weder deckungsgleich noch umstandslos kompatibel sind. Die Wahrheitsund die Sinnfrage sind in der Geschichtskultur wieder offen. Die Geschichtswissenschaft kann sich diesen Fragen nicht entziehen, wenn sie sich als Teil der Geschichtskultur der Gegenwart begreifen will, aber ebensowenig kann über Wahrheit und Sinn in allen Gefilden der Geschichtskultur plausibel nachgedacht und debattiert werden, ohne Leistung und Grenzen der wissenschaftlichen historischen Erkenntnis zu erörtern«. J. Rüsen, Zeit und Sinn, 14, $98 \mathrm{f}$.

45. W. Mommsen, Die Geschichtswissenschaft, 36; Rüsen, Zeit und Sinn, $103 \mathrm{f}$.

46. »... daß Religion sich in Geschichte und Gesellschaft verwirklicht, eine empirische Größe darstellt, Religion also ein soziales Phänomen ist, das im sozialen Handeln von Menschen, Gruppen und Gesellschaften gegründet ist, dann versagen weitgehend alle bekannten Definitionen. Religionshistorische Definitionsversuche sind entweder so different, daß sie sich zum Teil gegenseitig ausschließen, oder so allgemein und formal, daß sie sich für eine Erforschung konkreter religiöser Institutionen, Verhaltensweisen oder Symbolsysteme in der Geschichte als unzureichend erweisen. Verständlich ist daher, wenn die Geschichtswissenschaft einem Definitionsversuch ausweicht und sich an Begriffen der Alltagssprache orientiert. Denn für die Forschungspraxis reicht weder Ottos allgemeine Bestimmung der Religion als Erfahrung des Heiligen, noch die Menschings als erlebnishafte Begegnung mit heiliger Wirklichkeit und darauf antwortendes Handeln des Menschen. Die Orientierung beider an einer ahistorisch verfahrenden Phänomenologie ist offenkundig«. Richard van Dülmen, Religion und Gesellschaft. Beiträge zu einer Religionsgeschichte der Neuzeit, Frankfurt a.M. 1989, 216 f. Det drejer sig om en ældre artikel, »Religionsgeschichte in der historischen Sozialforschung «, Geschichte und Gesellschaft, 6, 1980, 36-58 (især 52-55), som jeg tidligere har taget stilling til (Historical Fundamentals and the Study of Religions, New York 1985, 32 f., 46). 


\section{Kurt Rudolph}

47. „Was Religion, religiöse Lehre und religiöse Symbolik sind, welche Funktion sie in der Gesellschaft ausüben, und umgekehrt, welche Rolle ihnen in der Geschichte, in historischen und sozialen Prozessen zukommt - wenn wir damit allgemein die Aufgaben einer Religionsforschung beschreiben wollen -, das läßt sich nicht unter den Bedingungen eines Religionsbegriffs und einer Religionstypologie fassen, die außerhalb von historischer Zeit und gesellschaftlichem Raum gewonnen wurden und an einem letztlich metahistorischen Wesen von Religion orientiert sind. Die Religionsphänomenologie und traditionelle Kirchengeschichte eröffnen somit keine Perspektive einer historischen Analyse von Religion. Religion ist außerhalb des sozialen Handelns des Menschen und seiner Gesellschaft nicht denkbar, dementsprechend kann sie auch nur aus dem jeweiligen Kontext der gesellschaftliche Formation und ihrer Voraussetzungen begriffen werden, in dem sie entstand oder in dem sie soziale og politische Bedeutung erlangt. Operierte die allgemeine Religionswissenschaft mit einer dem Wesen des Menschen mitgegebenen Größe von Religion, so kann sie religiöse Phänomene nur als religiös, als heilig und numinös begreifen, ihre soziale Rolle und ihren Charakter, ihre zentrale Funktion als Weltorientierungsmittel im gesellschaftlichen Prozeß jedoch nicht erkennbar machen. Eine historische Religionsforschung thematisiert Religion als ein soziales Phänomen und analysiert Religion auf dem Hintergrund der sie tragenden sozialen Interessen. Gerade diesen Interessen verdankt sie auch ihre spezifische Form. Eine neue Typologie könnte hier ansetzen«. R. van Dülmen, anf.arb., $218 \mathrm{f}$.

48. „Religion, Religiosität bzw. religiöse Phänomene lassen sich inhaltlich und formal also nicht generell aus sich selbst bestimmen, sondern nur in der sozialen Ordnung adäquat beschreiben und analysieren, in der sie für den Menschen und die Gesellschaft Wirklichkeit sind als religiöse Institution und gesellschaftliches Bewußtsein«. R. van Dülmen, anf.arb., 220.

49. H. G. Kippenberg, Die vorderasiatischen Erlösungsreligionen in ihrem Zusammenhang mit der antiken Stadtherrschaft. Heidelberger Max-Weber-Vorlesungen 1988, (suhrkamp taschenbuch wissenschaft 917), Frankfurt a.M. 1992.

50. Smst., 59.

51. Geschichte und Probleme der Religionswissenschaft, 75 ff., 89 f., 105; Historical Fundamentals and the Study of Religions, $67 \mathrm{ff}$.

52. Jf. Patzig, Tatsachen, Nomen, Sätze, 56 f.; Mommsen hos Rossi, Theorie der modernen Geschichtsschreibung, $132 \mathrm{f}$; udførligt hos Th. Hausmann (se note 39). ["H-Omodellen« er en model for videnskabelige forklaringers struktur, som blev opstillet af Carl Hempel og Paul Oppenheim i 1948. Ifølge modellen må en videnskabelig forklaring af en bestemt virkning ikke blot kunne pege på en bestemt årsag til den, men også kunne angive den generelle lov, den almengyldige grundsætning, ifølge hvilken virkningen er en logisk følge af årsagen. (oversætters anmærkning)]

53. Rüsen, Zeit und $\operatorname{Sinn}, 98 \mathrm{f}$. 


\section{Hvad religion er, fortæller historien os}

\section{Summary}

"What Religion is, History tells us. On the Relation between History and the Study of Religion" - Against Rudolf Otto and his like the article insists that there is no such thing as the essence of religion that can be grasped only by people equipped with some mysterious sort of religious intuition. Religion can only be studied as religions, i.e. in the different forms it assumes in various historical circumstances. Fundamentally the study of religion therefore must be a historical discipline and accordingly it can learn a lot from the new insights that have been won in history since the 1960's. The historical anthropology of the French Annales-school is mentioned, but the main focus of the article is on the impulses that can be found in the so-called whistorische Sozialwissenschaft developed by German historians. It is especially underlined that the theoretical discussions of this school have presented clues to old problems in the humanities, for instance the relation - so important in the history of the study of religion - between "Verstehen " and „Erklären«.

The article is a Danish translation of a lesson given by professor Rudolph in German at a conference on "Methodology in the Study of Religion", held at the University of Aarhus in June 1992.

\section{Kurt Rudolph}

Professor

Fachgebiet Religionsgeschichte

Philipps-Universität Marburg

Tyskland 